\title{
ESTIMATION OF LEAF AREA FOR GREENHOUSE CUCUMBER BY LINEAR MEASUREMENTS UNDER SALINITY AND GRAFTING
}

\author{
Flávio Favaro Blanco ${ }^{1 *}$; Marcos Vinícius Folegatti ${ }^{2}$ \\ ${ }^{I}$ Embrapa Meio Norte - Núcleo de Pesquisa dos Cerrados, Rod. BR 135, km 3 - 64900-000 - Bom Jesus, PI - \\ Brasil. \\ ${ }^{2}$ USP/ESALQ - Depto. de Engenharia Rural, C.P. 9 - 13418-900 - Piracicaba, SP - Brasil. \\ *Corresponding author <flavio@cpamn.embrapa.br>
}

\begin{abstract}
The measurement of leaf area by linear parameters is a useful tool when plants cannot be destroyed for direct measurement. The objectives of this study were to establish equations to estimate the leaf area of greenhouse-cucumber and to evaluate the effects of salinity and grafting on this estimative. Nongrafted cucumber seedlings, cv. 'Hokushin', were transplanted in a greenhouse and were irrigated with water of different salinities $\left(1.0,3.2\right.$ and $\left.5.0 \mathrm{dS} \mathrm{m}^{-1}\right)$. In the second growing period, the same cultivar was grafted on Cucurbita spp. and the plants were irrigated with water of 1.4, 3.0 and $5.3 \mathrm{dS} \mathrm{m}^{-1}$. Leaves of different sizes were collected from both experiments and leaf area was determined by an integrating area meter. Leaf length (L) and width (W) were also recorded. An equation for estimating the leaf area from $\mathrm{L}$ and $\mathrm{W}$ was developed for a given salinity level or grafting condition and estimated well the area of leaves collected in the other treatments. The leaf area (LA) of cucumber 'Hokushin' could be estimated using the equation $\mathrm{LA}=0.88 \mathrm{LW}$ -4.27 , for any grafting and salinity conditions.

Key words: Cucumis sativus L., regression, irrigation water salinity

\section{ESTIMATIVA DA ÁREA FOLIAR DO PEPINO EM AMBIENTE PROTEGIDO POR MEDIDAS LINEARES SOB SALINIDADE E ENXERTIA}

\begin{abstract}
RESUMO: A determinação da área foliar por medidas lineares é uma ferramenta útil quando as plantas não podem ser destruídas para que a medição direta seja realizada. Os objetivos desse trabalho foram definir equações para a estimativa da área foliar do pepino em ambiente protegido e avaliar os efeitos da salinidade e da a enxertia nessa estimativa. Mudas de pepino, cv. 'Hokushin', não enxertadas, foram transplantadas em um ambiente protegido e irrigadas com água de diferentes salinidades $\left(1,0,3,2\right.$ e 5,0 dS m $\left.{ }^{-1}\right)$. No segundo período de cultivo, a mesma cultivar foi enxertada sobre Cucurbita spp., sendo as plantas irrigadas com água de 1,4, 3,0 e 5,3 $\mathrm{dS} \mathrm{m}^{-1}$. Foram coletadas folhas de diferentes tamanhos dos dois cultivos e dos três tratamentos e a área foliar foi determinada por um medidor de área foliar. O comprimento (C) e a largura (L) da folha também foram registrados. Desenvolveram-se equações pelas quais a área foliar pôde ser estimada a partir de medidas de C e L. A equação desenvolvida para um dado nível de salinidade ou condição de enxertia estimou bem a área das folhas coletadas nos demais tratamentos. A área foliar (AF) do pepino 'Hokushin' pode ser estimada pela função $\mathrm{AF}=0,88 \mathrm{CL}-4,27$, para qualquer condição de enxertia e salinidade.

Palavras-chave: Cucumis sativus L., regressão, salinidade da água
\end{abstract}

\section{INTRODUCTION}

Leaf area is an important variable for most physiological and agronomic studies involving plant growth, light interception, photosynthetic efficiency, evapotranspiration and response to fertilizers and irrigation. Vegetable crops are very sensitive to the environmental conditions, such as soil salinity, which generally affects leaf area as well as plant yield and growth (Chartzoulakis, 1994; Folegatti \& Blanco, 2000; Blanco et al., 2002).

Determination of leaf area (LA) is generally made by direct methods, leaves being collected and measured with an electronic integrating area meter. This is a destructive method and restricted to equipment availability. Indirect methods are useful when this equipment is not available or non-destructive measurements are needed, such as field conditions or low plant density growing in pots of controlled experiments. One of the most frequently used non-destructive and indirect methods is estimating LA from mathematical equations involving linear measurements such as leaf length (L) and width (W), which usually have high accuracy as demonstrated for several vegetable crops, like cucumber (Robbins \& Pharr, 1987), lettuce (Guo \& Sun, 2001), tomato (Astegiano et 
al., 2001), strawberry (Strik \& Proctor, 1985) and pumpkin (Silva et al., 1998).

Environmental conditions seem to change leaf geometry of plants of the Cucurbitaceae family. Robbins \& Pharr (1987) verified that the leaves of cucumber grown in hydroponic sand culture were larger in total area and had different geometry in relation to plants grown in soil, thus changing the relation between $\mathrm{L}$ and W. Silva et al. (1998) reported that the equation developed for estimating LA for pumpkin growing in field conditions did not estimated well the LA for greenhouse-grown plants.

The objective of this study was to develop regression models that would accurately predict cucumber leaf area using linear measurements of $\mathrm{L}$ and $\mathrm{W}$ and to evaluate the effects of grafting and different levels of irrigation water salinity on this estimative.

\section{MATERIAL AND METHODS}

Data used in the present work were obtained from two experiments carried out in Piracicaba, SP $\left(22^{\circ} 43^{\prime} \mathrm{S}\right.$, $47^{\circ} 38^{\prime} \mathrm{W}$ ) to verify the response of grafted and nongrafted cucumbers to salinity.

\section{Experiment 1: Non-grafted cucumber}

A greenhouse of $1.6 \mathrm{~m}$ height, $10 \mathrm{~m}$ width, $20 \mathrm{~m}$ length was used, covered with a polyethylene film with $0.15 \mathrm{~mm}$ of thickness was used, with lateral curtains that were closed at night and opened during the day, containing three beds divided into nine plots of $1.85 \mathrm{~m}$ length and $1 \mathrm{~m}$ width, insulated by a plastic film buried down to $0.8 \mathrm{~m}$ to avoid salt exchange between two adjacent plots.

Cucumber seedlings, cv. 'Hokushin', were transplanted on January 13, 1999, on beds with two rows, giving a plant density of 2.5 plants $\mathrm{m}^{-2}$. Plants were trained with a single stem along and around a vertical plastic string. Water was applied by a drip irrigation system, with one dripper per plant, and $\mathrm{N}, \mathrm{P}, \mathrm{K}, \mathrm{Ca}, \mathrm{Mg}$ and $\mathrm{S}$ were applied with the irrigation water of all irrigations, following the nutrient uptake rate of cucumber in greenhouse.

Three water salinity levels were used: $1.0 \mathrm{dS} \mathrm{m}^{-1}$ (S1); $3.2 \mathrm{dS} \mathrm{m}^{-1}$ (S2) and $5.0 \mathrm{dS} \mathrm{m}^{-1}$ (S3). Treatment $\mathrm{S} 1$ received only fertilizers, while $\mathrm{S} 2$ and $\mathrm{S} 3$, salts in order to reach the desired salinity level. The salts were calcium chloride, magnesium sulphate and sodium chloride, which were mixed in order to obtain a nutrient solution for $\mathrm{S} 2$ and $\mathrm{S} 3$ with $(\mathrm{Na}+\mathrm{K}): \mathrm{Ca}: \mathrm{Mg}$ ratio of 5:3:2. Irrigation was controlled through tensiometers and pan evaporation measurements. Tensiometers were installed in each plot at 0.15 and $0.30 \mathrm{~m}$ depth, placed $0.10 \mathrm{~m}$ from the plant and the dripper, and readings were made daily in the morning. Water was applied whenever the mean soil matric potential was bellow $-30 \mathrm{kPa}$ and the irrigation water depth was calculated based on pan evaporation. Ir- rigation started at 14 days after transplanting (DAT) because no tensiometer response was observed before, and it had an average frequency of 2 days and a volume of $0.850 \mathrm{~L}_{\text {plant }}{ }^{-1}$ day $^{-1}$.

At 40 days after transplanting (DAT), 24 leaves of each treatment were collected; L and $\mathrm{W}$ of each leaf were measured with a simple ruler and leaf area (LA) was measured in a LI-COR 3000 leaf area meter. L was measured from the lamina tip to the point of intersection of the lamina and petiole and $\mathrm{W}$ was measured from tip to tip between the widest lamina lobes (Figure 1).

\section{Experiment 2: Grafted cucumber}

In the second experiment, cucumber, cv. 'Hokushin', seedlings were grafted on squash (Cucurbita spp.), hybrid 'Excite-Ikki', and cultivated in another greenhouse $6.3 \mathrm{~m}$ wide, $17.5 \mathrm{~m}$ long and $2.8 \mathrm{~m}$ height, with polyethylene cover with $0.15 \mathrm{~m}$ of thickness. Plant density, training, irrigation and fertilization were the same of the first experiment. Water salinities were $1.4 \mathrm{dS} \mathrm{m}^{-1}$ (S1), $3.0 \mathrm{dS} \mathrm{m}^{-1}$ (S2) and $5.3 \mathrm{dS} \mathrm{m}^{-1}$ (S3).

Seedlings were transplanted on 23 June 1999, and irrigation started at 19 DAT, with an average frequency and volume of 3.8 days and $0.144 \mathrm{~L}_{\text {plant }}{ }^{-1}$ day $^{-1}$, respectively. Higher irrigation interval and lower water uptake by plants in relation to experiment 1 was due to the lower temperature in the autumn-winter period. Leaf measurements were performed at 35 DAT as for the non-grafted plants.

\section{Comparison of the regression equations}

Values of $\mathrm{L}, \mathrm{W}$ and the product LW were plotted against LA and regression models were obtained for each water salinity level. Coefficients of determination $\left(\mathrm{R}^{2}\right)$ and the standard errors (SE) were calculated and the equation that presented the highest $\mathrm{R}^{2}$ and the lowest $\mathrm{SE}$ was used in the estimations. The best equation obtained for each

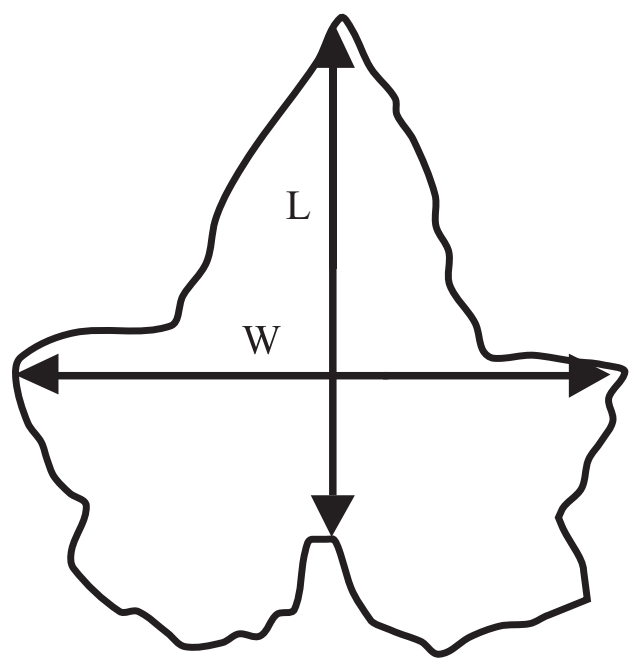

Figure 1 - Diagram of cucumber leaf showing positions of length (L) and width (W) measurements. 
treatment was used to estimate the LA of the other treatments of the same experiment, in order to evaluate the ability of the equation fitted with data from a specific water salinity in estimating the LA of the leaves coming from different salinity conditions.

Best equations obtained for experiment 1 and 2 were used to estimate LA of experiment 2 and 1, respectively, of the same treatment, in order to evaluate the effects of the grafting on the estimative of leaf area. A linear model $(y=b x+a)$ was fitted, where $y$ is the measured leaf area $\left(\mathrm{cm}^{2}\right), \underline{b}$ is the slope, $\underline{x}$ is the predicted LA value and a the intercept.

\section{RESULTS AND DISCUSSION}

Equations obtained for estimating the LA of nongrafted and grafted cucumber are shown in Table 1. The equations that use only $\mathrm{L}$ had the lowest $\mathrm{R}^{2}$ values and the highest of SE, thus resulting in poor LA estimation when compared to those that use $\mathrm{W}$ or the product LW, for both experiments and all treatments. The best equations were those that use LW, giving the highest $\mathrm{R}^{2}$ and lowest SE. Other authors also reported better relationships between LA and LW for several crops, such as strawberry (Strik \& Proctor, 1985), safflowers (Sepaskhah, 1977), lettuce (Guo \& Sun, 2001) and taro (Lu et al., 2004). In spite of the fact that these equations require more time in determining LA because L and W should be measured, they were used in the analysis due to the high precision and low errors of the predictions.

\section{Influence of irrigation water salinity on prediction of LA}

Irrigation water salinity did not influence the leaf area estimations and the statistical coefficients were practically the same when an equation obtained from a given salinity level was used to estimate the LA of leaves from other salinity levels (Table 2).

For non-grafted cucumber, the poorer prediction was that obtained with the Eq.(3) for leaves taken from S2 and S3 treatments, which resulted in an underestimation of LA of 2.5\%, and Eq.(9) for S1, with an overestimation of $2.4 \%$. Highest underestimation for the grafted cucumber was that given by the Eq.(15), which was of $2.9 \%$ for estimating the LA of S3, and the highest overestimation was $2.6 \%$ when Eq.(18) was used on S2.

The highest SE and lowest $\mathrm{R}^{2}$ of the estimations were obtained for $\mathrm{S} 1$ on both experiments. Leaf area of the leaves taken from S3 treatment for non-grafted cucumber and from S2 for grafted cucumber were well predicted by the equations fitted for others treatments and presented the lowest $\mathrm{SE}$ and highest $\mathrm{R}^{2}$. Besides the fact that some estimates were less precise with higher overor underestimation than others, all equations showed a

Table 1 - Equations for predicting cucumber leaf area (LA) from length (L), width (W) or the product LW and the corresponding coefficient of determination $\left(\mathrm{R}^{2}\right)$ and standard error (SE) for non-grafted and grafted cucumber irrigated with water of different salinities.

\begin{tabular}{|c|c|c|c|c|c|}
\hline Crop & Water Salinity (S) & Equation $^{\#}$ & Equation number & $\mathrm{R}^{2}$ & SE \\
\hline & $\mathrm{dS} \mathrm{m}^{-1}$ & & & & \\
\hline \multirow[t]{9}{*}{ Non-grafted cucumber } & $1.0(\mathrm{~S} 1)$ & $\mathrm{LA}=38.15 \mathrm{~L}-333$ & $\mathrm{Eq}(1)$ & 0.906 & 35.77 \\
\hline & & $\mathrm{LA}=38.2 \mathrm{~W}-503$ & $\mathrm{Eq}(2)$ & 0.940 & 28.59 \\
\hline & & $\mathrm{LA}=0.86 \mathrm{LW}+2.7$ & $\mathrm{Eq}(3)$ & 0.978 & 26.40 \\
\hline & $3.2(\mathrm{~S} 2)$ & $\mathrm{LA}=1.67 \mathrm{~L}^{2}-23.23 \mathrm{~L}+205$ & $\mathrm{Eq}(4)$ & 0.909 & 42.76 \\
\hline & & $\mathrm{LA}=36.3 \mathrm{~W}-439$ & $\mathrm{Eq}(5)$ & 0.970 & 25.41 \\
\hline & & $\mathrm{LA}=0.885 \mathrm{LW}-3.5$ & $\mathrm{Eq}(6)$ & 0.978 & 22.50 \\
\hline & $5.0(\mathrm{~S} 3)$ & $\mathrm{LA}=1.672 \mathrm{~L}^{2}-23.23 \mathrm{~L}+205$ & $\mathrm{Eq}(7)$ & 0.978 & 29.00 \\
\hline & & $\mathrm{LA}=0.678 \mathrm{~W}^{2}+5.87 \mathrm{~W}-105$ & $\mathrm{Eq}(8)$ & 0.976 & 25.94 \\
\hline & & $\mathrm{LA}=0.943 \mathrm{LW}-32.44$ & $\mathrm{Eq}(9)$ & 0.983 & 21.27 \\
\hline \multirow[t]{9}{*}{ Grafted cucumber } & $1.4(\mathrm{~S} 1)$ & $\mathrm{LA}=1.16 \mathrm{~L}^{2}-3.1 \mathrm{~L}+11.6$ & $\mathrm{Eq}(10)$ & 0.988 & 32.70 \\
\hline & & $\mathrm{LA}=0.36 \mathrm{~W}^{2}+11.92 \mathrm{~W}-88$ & $\mathrm{Eq}(11)$ & 0.987 & 23.99 \\
\hline & & $\mathrm{LA}=0.8533 \mathrm{LW}-1.03$ & $\mathrm{Eq}(12)$ & 0.991 & 15.89 \\
\hline & $3.0(\mathrm{~S} 2)$ & $\mathrm{LA}=1.33 \mathrm{~L}^{2}-8.85 \mathrm{~L}+55.4$ & $\mathrm{Eq}(13)$ & 0.993 & 34.79 \\
\hline & & $\mathrm{LA}=24.9 \mathrm{~W}-189$ & $\mathrm{Eq}(14)$ & 0.987 & 19.74 \\
\hline & & $\mathrm{LA}=0.84 \mathrm{LW}+2.75$ & $\mathrm{Eq}(15)$ & 0.995 & 11.50 \\
\hline & $5.3(\mathrm{~S} 3)$ & $\mathrm{LA}=1.08 \mathrm{~L}^{2}-1.03 \mathrm{~L}+4.7$ & $\mathrm{Eq}(16)$ & 0.984 & 32.60 \\
\hline & & $\mathrm{LA}=0.367 \mathrm{~W}^{2}+12.2 \mathrm{~W}-87.6$ & $\mathrm{Eq}(17)$ & 0.989 & 19.25 \\
\hline & & $\mathrm{LA}=0.868 \mathrm{LW}+1.08$ & $\mathrm{Eq}(18)$ & 0.992 & 13.72 \\
\hline
\end{tabular}

\# Values of LA in $\mathrm{cm}^{2}, \mathrm{~L}$ and $\mathrm{W}$ in $\mathrm{cm}$. 
good ability in estimating LA for any treatment. Therefore, the relation between $\mathrm{L}$ or $\mathrm{W}$ to LA was maintained practically the same, independently of the salinity of the irrigation water. Little differences of $\mathrm{R}^{2}$ or $\mathrm{SE}$ could also be attributed to the errors in the leaf $\mathrm{L}$ and $\mathrm{W}$ measurements.

\section{Influence of grafting on prediction of LA}

The best equation of each treatment of experiments 1 and 2 was used to estimate the LA of experiment 2 and 1 , respectively. The linear model was forced to pass through the origin because the intercept was very close to zero. Thus a became zero and $\underline{b}$ indicated how much the estimations were above $(b>1)$ or bellow $(b<1)$ the measured LA values.

The equations fitted to data of the S2 treatment had the worst precision, which underestimated in 3.9\% the LA of non-grafted cucumber and overestimated in $3.8 \%$ for grafted cucumber (Table 3). However, the SE and $\mathrm{R}^{2}$ were satisfactory and the discrepancies observed for $\underline{b}$ values were probably because the regression was forced through the origin. In a general way, high $\mathrm{R}^{2}$ and low SE values of the estimations for both experiments indicated that the relation between L or W to LA was unaltered by grafting.

\section{General equation for estimating LA}

A common regression equation could be used to predict leaf area of non-grafted and grafted cucumber $\mathrm{cv}$. 'Hokushin' under different levels of salinity, once both factors did not exercise effects on the relation between $\mathrm{L}$ or $\mathrm{W}$ to LA. Figure 2 shows the relations of L, W and LW with the measured leaf area and the regression equations for predicting LA from these variables. The equation with LW as independent variable should be used due to the highest $\mathrm{R}^{2}$ and lowest $\mathrm{SE}$ in relation to the other. In addition, LA can be estimated only by multiplying the LW product by a constant of 0.88 and subtracting from 4.27, which make the estimation very simple to be used in the field. Equations with $\mathrm{L}$ or $\mathrm{W}$ as independent variables also could be used, with some sacrifice in accuracy due to the higher SE.

Table 2 - Standard error (SE), coefficient of determination $\left(\mathrm{R}^{2}\right)$ and linear regression slope (b) for the estimation of the leaf area of non-grafted and grafted cucumber irrigated with water of different salinities, using the best equations developed for each treatment.

\begin{tabular}{|c|c|c|c|c|c|c|c|c|c|}
\hline \multirow{4}{*}{ Water salinity $(\mathrm{S})$} & \multicolumn{9}{|c|}{ Equation used to estimate the leaf area } \\
\hline & \multicolumn{9}{|c|}{ Non-grafted cucumber } \\
\hline & \multicolumn{3}{|c|}{$\mathrm{Eq}(3)$} & \multicolumn{3}{|c|}{$\mathrm{Eq}(6)$} & \multicolumn{3}{|c|}{$\mathrm{Eq}(9)$} \\
\hline & SE & $\mathrm{R}^{2}$ & $\mathrm{~b}$ & SE & $\mathrm{R}^{2}$ & $\mathrm{~b}$ & SE & $\mathrm{R}^{2}$ & $\mathrm{~b}$ \\
\hline $\mathrm{dS} \mathrm{m^{-1 }}$ & $\mathrm{cm}^{2}$ & & & $\mathrm{~cm}^{2}$ & & & $\mathrm{~cm}^{2}$ & & \\
\hline $1.0(\mathrm{~S} 1)$ & - & - & - & 26.4 & 0.950 & 1.021 & 26.4 & 0.950 & 1.024 \\
\hline $3.2(\mathrm{~S} 2)$ & 22.5 & 0.971 & 0.975 & - & - & - & 22.5 & 0.974 & 1.001 \\
\hline \multirow[t]{5}{*}{$5.0(\mathrm{~S} 3)$} & 21.3 & 0.975 & 0.975 & 21.3 & 0.980 & 0.997 & - & - & - \\
\hline & \multicolumn{9}{|c|}{ Grafted cucumber } \\
\hline & \multicolumn{3}{|c|}{$\operatorname{Eq}(12)$} & \multicolumn{3}{|c|}{$\operatorname{Eq}(15)$} & \multicolumn{3}{|c|}{$\operatorname{Eq}(18)$} \\
\hline & $\mathrm{SE}$ & $\mathrm{R}^{2}$ & $\mathrm{~b}$ & SE & $\mathrm{R}^{2}$ & $\mathrm{~b}$ & $\mathrm{SE}$ & $\mathrm{R}^{2}$ & $\mathrm{~b}$ \\
\hline & $\mathrm{cm}^{2}$ & & & $\mathrm{~cm}^{2}$ & & & $\mathrm{~cm}^{2}$ & & \\
\hline $1.4(\mathrm{~S} 1)$ & - & - & - & 15.9 & 0.991 & 0.992 & 15.9 & 0.991 & 1.020 \\
\hline $3.0(\mathrm{~S} 2)$ & 11.5 & 0.995 & 1.003 & - & - & - & 11.5 & 0.996 & 1.026 \\
\hline $5.3(\mathrm{~S} 3)$ & 13.7 & 0.992 & 0.975 & 13.7 & 0.992 & 0.971 & - & - & - \\
\hline
\end{tabular}

Table 3 - Standard error (SE), coefficient of determination $\left(\mathrm{R}^{2}\right)$ and linear regression slope $(b)$ for the estimation of the leaf area of non-grafted and grafted cucumber by the equations developed for grafted and non-grafted cucumber, respectively.

\begin{tabular}{lccccc}
\hline Crop & Water salinity (S) & Equation & $\mathrm{SE}$ & $\mathrm{R}^{2}$ & $\mathrm{~b}$ \\
\hline \multirow{2}{*}{ Non-grafted cucumber } & $\mathrm{dS} \mathrm{m}{ }^{-1}$ & & $\mathrm{~cm}^{2}$ & & \\
& $1.0(\mathrm{~S} 1)$ & $\mathrm{Eq}(12)$ & 25.9 & 0.935 & 0.989 \\
& $3.2(\mathrm{~S} 2)$ & $\mathrm{Eq}(15)$ & 22.5 & 0.948 & 0.961 \\
Grafted cucumber & $5.0(\mathrm{~S} 3)$ & $\mathrm{Eq}(18)$ & 15.0 & 0.966 & 1.013 \\
& $1.4(\mathrm{~S} 1)$ & $\mathrm{Eq}(3)$ & 19.9 & 0.980 & 1.013 \\
& $3.0(\mathrm{~S} 2)$ & $\mathrm{Eq}(6)$ & 16.4 & 0.983 & 1.038 \\
\hline
\end{tabular}



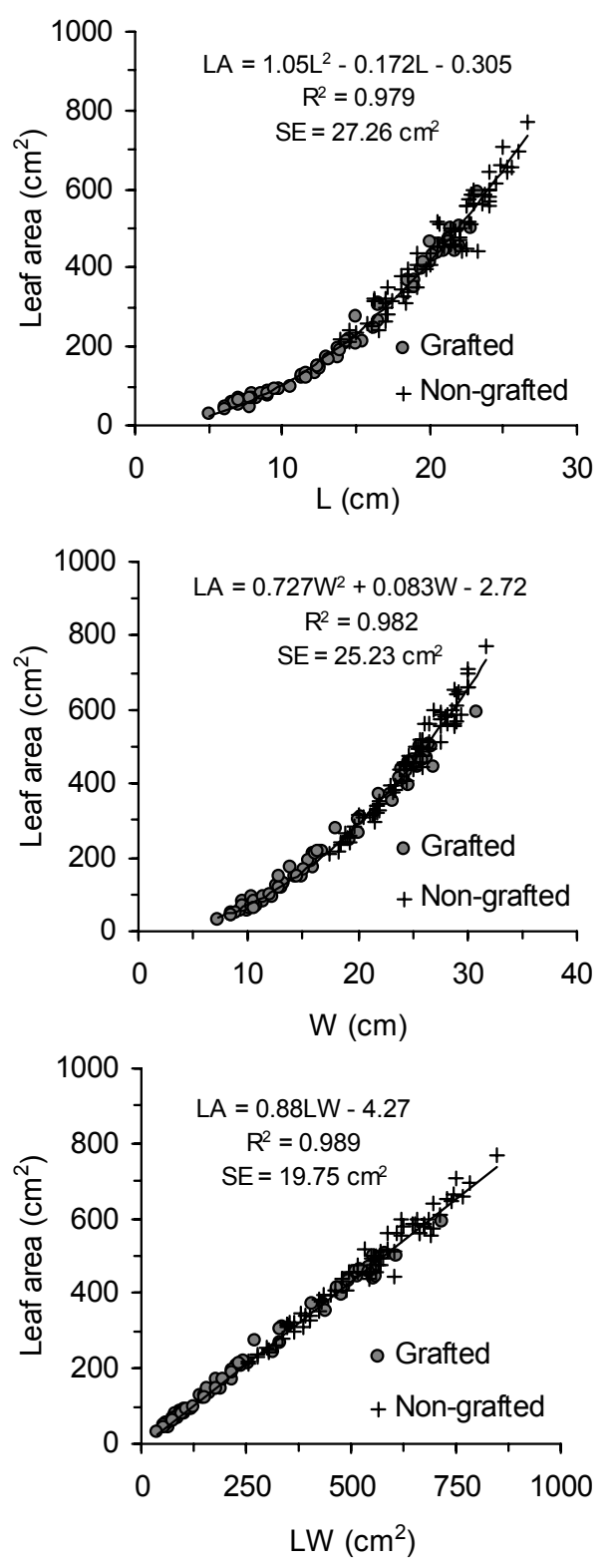

Figure 2 - General regression models for estimating the leaf area of non-grafted and grafted cucumber from leaf length (L), width $(\mathrm{W})$ or the product LW. Each equation includes all treatments.

In North Carolina, USA, Robbins \& Pharr (1987) found $\mathrm{LA}=0.89 \mathrm{LW}-20.58\left(\mathrm{R}^{2}=0.98\right)$ for soil-grown Calypso cucumber, and no difference was found between this model and the models fitted for 14 soil-grown cucumber cultivars in field and greenhouse. Leaf area of 'Hokushin' cucumber measured in the present study was estimated by the model for Calipso cucumber (Robbins $\&$ Pharr, 1987) and an error of only $2.7 \%$ was found (Fig-

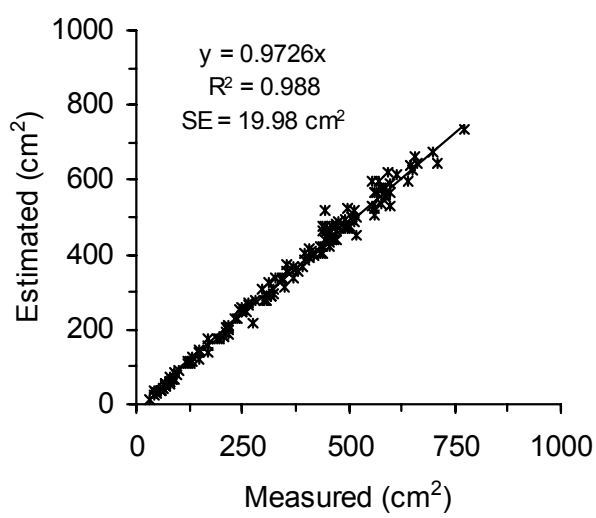

Figure 3 - Measured and estimated leaf area of 'Hokushin' cucumber using the model for 'Calipso' cucumber.

ure 3), which suggests that the relation between $\mathrm{W}$ or $\mathrm{L}$ to LA of soil-grown cucumber has only little differences between the cultivars, location and growing systems.

\section{ACKNOWLEDGMENT}

To FAPESP for financial support.

\section{REFERENCES}

ASTEGIANO, E.D.; FAVARO, J.C.; BOUZO, C.A. Estimación del area foliar en distintos cultivares de tomate (Lycopersicon esculentum Mill.) utilizando medidas foliares lineales. Investigación Agraria: Producción y Protección Vegetales, v.16, p.249-256, 2001.

BLANCO, F.F.; FOLEGATTI, M.V.; NOGUEIRA, M.C.S. Fertirrigação com água salina e seus efeitos na produção do pepino enxertado em ambiente protegido. Horticultura Brasileira, v.20, p.442-446, 2002.

CHARTZOULAKIS, K.S. Photosynthesis, water relations and leaf growth of cucumber exposed to salt stress. Scientia Horticulturae, v.59, p.2735, 1994.

FOLEGATTI, M.V.; BLANCO, F.F. Desenvolvimento vegetativo do pepino enxertado irrigado com água salina. Scientia Agricola, v.57, p.451-457, 2000.

GUO, D.P.; SUN, Y.Z. Estimation of leaf area of stem lettuce (Lactuca sativa var angustana) from linear measurements. Indian Journal of Agricultural Sciences, v.71, p.483-486, 2001.

LU, H.Y.; LU, C.T.; WEI, M.L.; CHAN, L.F. Comparison of different models for nondestructive leaf area estimation in taro. Agronomy Journal, v.96, p.448-453, 2004.

ROBBINS, N.S.; PHARR, D.M. Leaf area prediction models for cucumber from linear measurements. HortScience, v.22, p.1264-1266, 1987.

SEPASKHAH, A.R. Estimation of individual and total leaf areas of safflowers. Agronomy Journal, v.69, p.783-785, 1977.

SILVA, N.F.; FERREIRA, F.A.; FONTES, P.C.R.; CARDOSO, A.A. Modelos para estimar a área foliar de abóbora por meio de medidas lineares. Revista Ceres, v.45, p.287-291, 1998.

STRIK, B.C.; PROCTOR, J.T.A. Estimating the area of trifoliolate and unequally imparipinnate leaves of strawberry. HortScience, v.20, p.1072-1074, 1985.

Received June 06, 2004

Accepted May 31, 2005 